\title{
JUURNAL.RU
}

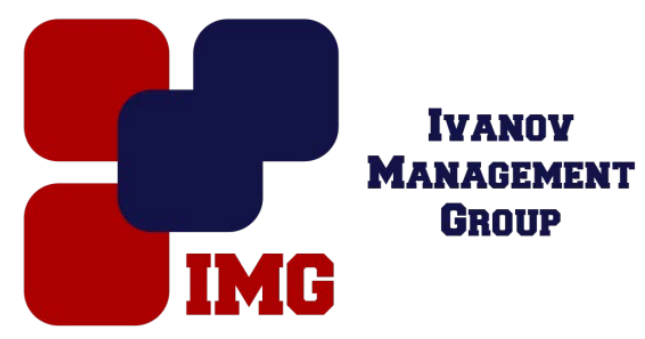

Васюкова А.Н. ФГБОУ ВО Дальневосточный государственный аграрный университет Благовещенск, Россия

doi: 10.18411/lj-31-10-2016-3-01

idsp 000001:lj-31-10-2016-3-01

\section{Исследование антиоксидантных свойств проростков сои на лабораторных животных в условиях охлаждения}

Холод - весьма распространенный физический стресс-фактор, сопровождающий человека в его профессиональной деятельности и в условиях временного или продолжительного пребывания в суровых климатогеографических условиях. Доказано, что холод в зависимости от интенсивности и длительности воздействия является фактором риска для здоровья и жизнедеятельности человека с поражением практически всех функциональных систем организма [2,3].

При охлаждении происходит усиление процессов перекисного окисления липидов (ПОЛ), нарушение координации компонентов антиоксидантной системы. Резкое усиление окислительных процессов при недостаточности системы антиоксидантной защиты приводит к развитию «оксидантного стресса», который рассматривается как один из общих механизмов повреждения тканей организма.

В последнее время при поиске криопротекторов исследователи уделяют всё больше внимания биологически активным природным соединениям. Цель настоящего исследования - оценка перспективности проростков сои для коррекции метаболических изменений в организме животных в условиях экстремально низкой температуры.

Антиоксидантные свойства проростков сои изучались на лабораторных животных (белые мыши - самцы) по изменению содержания продуктов ПОЛ 
(гидроперекиси липидов, диеновые конъюгаты, малоновый диальдегид) и компонента антиоксидантной системы - витамина Е. Биохимические исследования плазмы крови лабораторных животных проводились на кафедре биохимии ГБОУ ВПО Амурская государственная медицинская академия.

В эксперименте использованы белые беспородные половозрелые мышисамцы (виварий ФГБОУ ВО Дальневосточный ГАУ) с исходной массой тела 1820 г. До начала исследования для адаптации лабораторные животные находились при групповом содержании в клетках в течение 14 дней. Во время этого периода у мышей ежедневно контролировали клиническое состояние путем визуального осмотра.

После акклиматизационного периода были сформированы группы животных, соответственно дизайну эксперимента. Все мыши были разделены на 4 группы по 6 животных в каждой. Одна группа лабораторных животных была контрольной. Остальные пять группы были экспериментальными с оценкой воздействия различных факторов питания и охлаждения:

1) контрольная - стандартное питание вивария;

2) І опыт - с добавлением 10 \% высушенных проростков;

3) II опыт - основной рацион с охлаждением;

4) III опыт - с добавлением $10 \%$ высушенных проростков и охлаждением;

Мыши содержались в стандартных условиях в соответствии с «Руководством по содержанию и использованию лабораторных животных» и ГОСТ Р 53434-2009. Животные содержались в поликарбонатных клетках, группами по 6 особей, на подстиле из бумаги и сена, получали корм и воду без ограничения. На момент проведения экспериментов животные были здоровыми, изменений поведения, аппетита, режима сна и бодрствования обнаружено не было. Контроль за состоянием животных и поедаемостью корма проводили ежедневно [4].

Для получения добавки 6-дневные проростки сои высушивали при температуре $40^{\circ} \mathrm{C}$ и измельчали. Корм для лабораторных животных также измельчали, добавляли в него порошок из высушенных проростков, в смесь добавляли воду и перемешивали. Однородную массу продавливали через 
отверстия диаметром 3 мм для получения гранул, которые затем высушивали при комнатной температуре.

Животных II - III опытных групп ежедневно в утреннее время помещали на 2 часа в климатокамеру при температуре $-5^{\circ} \mathrm{C}$ в течение 20 дней. В созданных условиях происходят значительные биохимические изменения, проявляющиеся в колебании содержания перекисных продуктов в соответствии с развитием стадий приспособительного процесса.

На протяжении всего эксперимента животные находились под ежедневным наблюдением: отмечалось их поведение, потребление корма и воды, состояние волосяного покрова и слизистых оболочек, изменений в весе животных (взвешивали раз в неделю).

Взятие крови у мышей всех групп после окончания опыта проводили декапитацией, сопровождавшейся адекватной анестезией с использованием диэтилового эфира (с добавлением в отношении 1:10 3\% раствора цитрата натрия).

МДА в плазме крови определяли по цветной реакции с тиобарбитуровой кислотой; диеновые конъюгаты - спектрофотометрически в спиртовом растворе; количество гидроперекисей липидов определяли на основе их способности окислять ионы $\mathrm{Fe} 2+\mathrm{c}$ последующей реакцией на Fe3+ c тиоцианатом аммония. Содержание токоферола определяли в липидных экстрактах плазмы крови по цветной реакции с дипиридилом и $\mathrm{FeCl} 3$.

Во всех опытах группы «Контроль» отмечалось статистически значимое снижение вторичных продуктов липопероксидации в плазме крови, а также возрастание концентрации витамина $\mathrm{E}(\mathrm{p}<0,05)$.

Содержание гидроперекиси липидов в контрольной группе составило 82,3 нмоль/мл. В опыте I этот показатель снизился на 15 \%, что явно свидетельствует об уменьшении активности реакций ПОЛ.

Малоновый диальдегид (МДА) является более информативным показателем окислительных процессов в тканях. Исследуемая добавка к пище способствовали снижению концентрации МДА в сыворотке крови относительно контроля в варианте с сухими проростками в 3 раза. 
Показательна динамика содержания диеновых конъюгатов. Согласно полученным данным, при введении в рацион сухих проростков концентрация ДК достоверно снижалась на 40,8 \% по сравнению с контролем.

Многие флавоноиды действуют как хелаторы ионов металлов переменной валентности и способны, таким образом, ингибировать процессы ПОЛ [5]. Кроме того, флавоноиды, аналогично $\alpha$-токоферолу и холестерину, стабилизируют мембраны и выступают в качестве структурных антиоксидантов.

Одним из интегративных показателей состояния активности антиоксидантной системы крови, а также и антирадикальной защиты клеток является уровень витамина $\mathrm{E}$ [1].

Концентрация $\alpha$-токоферола в сыворотке крови белых мышей на фоне добавки составила 50,4 мкг/мл и превосходила этот показатель у контрольных животных на 49,1\%.

Таблица 1

Уровень продуктов ПОЛ и витамина Е в плазме крови животных опытных групп

\begin{tabular}{|c|c|c|c|c|}
\hline \multirow{2}{*}{ Метаболиты } & \multicolumn{2}{|c|}{$21^{\circ} \mathrm{C}$} & \multicolumn{2}{c|}{$-5^{\circ} \mathrm{C}$} \\
& \multicolumn{2}{|c|}{ Группа «Контроль» } & \multicolumn{2}{c|}{ Группа «Холод» } \\
\cline { 2 - 5 } & Контроль & I & II & III \\
\hline Диеновые коньюгаты, нмоль/Г & 268,1 & 158,7 & 351,2 & 238,8 \\
\hline МДА, нмоль/Г & 6,4 & 5,2 & 13,4 & 11,5 \\
\hline Гидроперекиси липидов, нмоль/Г & 82,3 & 68,7 & 148,1 & 127,4 \\
\hline Витамин Е, мкг/мл & 33,8 & 50,4 & 26,0 & 30,3 \\
\hline
\end{tabular}

При сравнении биохимических показателей групп «Контроль» и «Холод» были получены следующие данные. В опыте II было выявлено повышение на 31 \% диеновых конъюгат, повышение в 2,1 раза содержание МДА, увеличение в 1,8 раза содержания гидроперекисей, снижение концентрации витамина Е на $23 \%$. Это говорит о функциональном снижении антиоксидантной системы. Результатом холодового стресса является возрастающее количество гидроперекисей и образование свободных радикалов, разрушающих клеточные мембраны. При накоплении окислительных метаболитов в клетках, тканях и биологических жидкостях наблюдается нарушение функций биологических мембран и внутриклеточного обмена веществ и, как следствие, патологические изменения функций организма животных и человека [2,3].

В плазме крови мышей, подвергавшихся охлаждению и получавших с основным рационом сухие проростки, по сравнению с группой II наблюдается снижение количества диеновых конъюгат на 32 \%, заметное (статистически не 
значимое) снижение количества МДА на 31\%, некоторая тенденция к снижению уровня гидроперекисей (на 14 \%) и увеличению содержания витамина Е (на 16,4 \%). Таким образом отмечается проявление антиоксидантной защиты под влиянием БАВ проростков сои.

Результаты эксперимента свидетельствовали о снижении интенсивности свободнорадикального окисления липидов биомембран на фоне введения в рацион проростков сои, что связано с наличием в них комплекса биологически активных веществ. Содержащиеся в проростках флавоноиды и витамины препятствуют генерации свободных радикалов, уменьшают их концентрацию в мембранах, защищая молекулы от переокисления, проявляя иммунорегуляторное действие.

При действии холода и коррекции активации ПОЛ проростками сои уровни диеновых конъюгат, МДА, гидроперекисей и витамина Е мало отличаются от контрольной группы, то есть биологически активные вещества проростков сои компенсируют отрицательные стороны холодового воздействия и поддерживают антиоксидантную защиту.

Проростки сои являются перспективным сырьём для разработки технологий биологически активных добавок антиоксидантного действия для функционального питания населения северных регионов. 


\section{Литература}

1. Габриэлян, Н.И. Методы определения витамина Е в сыворотке крови / Н.И. Габриэлян, Э.Г. Левицкий, О.И. Щербакова / Тер. архив. 1983; 6:76-8.

2. Голохваст, К.С. Некоторые аспекты механизма влияния низких температур на человека и животных / К.С. Голохваст, В.В. Чайка // Вестн. новых мед. технологий. 2011. Т. 18, № 2. С. 486-489.

3. Деев, Л.И. Влияние холодового стресса на содержание и активность микросомального цитохрома Р 450 печени крыс / Л.И. Деев, М.Я. Ахалая, Ю.Б. Кудряшов // Бюл. эксперим. биологии. - 1981. - Т.91, №8. - С. 27 - 30.

4. Приложение к приказу Министерства здравоохранения СССР № 755 от 12.03.1977 г. Правила проведения работ с использованием экспериментальных животных.

5. Симонова, Н.П. Коррекция окислительного стресса природными антиоксидантами / Н.П. Симонова, М.А. Штарберг, Р.А. Анохина / Бюллетень физиологии и патологии дыхания. - Вып. 53. - 2014. - С. 8488. 